\title{
The Paraná Speaks English Program in Teacher Education
}

\section{O Programa Paraná fala Inglês na Formação de Professores}

Fábio Henrique Rosa Senefonte*

*Universidade Estadual do Norte do Paraná (UENP), Cornélio Procópio, Paraná / Brasil fabiosenefonte@uenp.edu.br

https://orcid.org/0000-0002-8343-7165

\begin{abstract}
At the interface between internationalization and language policies (ALTBACH; KNIGHT, 2007), the Paraná Speaks Languages (English) Program emerges as a strategy for the internationalization of universities in the state of Paraná. In this respect, this qualitative case study endeavored to describe and explain the extent to which the Program can contribute to the process of continuing teacher education. In addition, the study sought to discuss future actions, mediated by the Program, aiming at an improvement in teacher education. Through theoretical-methodological sessions and semi-structured interviews, the study involved three English teachers and a pedagogical coordinator. Results indicate that the continuing teacher education in the Program is characterized by didactic-pedagogical and administrative challenges and benefits (gains) in terms of pragmatic, cognitive and empowerment domains.
\end{abstract}

Keywords: internationalization; language policies; Paraná speaks English; teacher education.

Resumo: $\mathrm{Na}$ interface entre internacionalização e políticas linguísticas (ALTBACH; KNIGHT, 2007), o programa O Paraná fala Idiomas (inglês) surge como uma estratégia de internacionalização de universidades do estado do Paraná. Nesse viés, este estudo de caso, de natureza qualitativa, objetivou descrever e explicar de que forma, se alguma, o referido programa pode contribuir para o processo de formação continuada de professores. Além disso, o estudo buscou discutir futuras ações, mediadas pelo Programa, com vistas ao fomento da formação de professores. Por meio de sessões de discussões teórico-metodológicas e entrevistas semiestruturadas, o estudo envolveu três professores de inglês e um coordenador pedagógico. Os resultados apontam que a formação continuada de professores no Programa é caracterizada por desafios com questões didático-pedagógicas e administrativas e por benefícios (ganhos) em termos pragmáticos, cognitivos e de empoderamento.

Palavras-chave: internacionalização; políticas linguísticas; O Paraná fala inglês; formação de professores. 


\section{Introduction}

The contemporary world has become more and more globalized and this, in turn, has forced the interconnectedness of people, institutions and so forth. In this context, the internationalization of higher education arises as a compelling demand of globalization. Hence, higher education institutions all over the world have taken actions to grapple with such scenario and the Paraná Speaks English Program (PSE, henceforth) is one of them.

Since 2014, the institutional Program named "Paraná Speaks Languages" (English) has served the 7 state universities of Paraná in Brazil, namely: UEL (State University of Londrina), UEM (State University of Maringá), UEPG (State University of Ponta Grossa), UNESPAR (State University of Paraná), UNICENTRO (State University of Midwestern Paraná), UNIOESTE (State University of Western Paraná) and UENP (State University of Northern Paraná). Such Program, as a language policy, acts in different dimensions of the academic universe, such as: improving the quality of higher education and strengthening the internationalization of universities (MARSON, 2017; SETI, 2020). In addition, the Program indirectly contributes to (continuing) teacher education, as the language instructors of PSE are provided with situations of a theoretical-praxiological nature (viz.: classroom practice, pedagogical counselling and others).

Bearing this in mind, this investigation focuses on (continuing) teacher education mediated by the Paraná Speaks English Program. Therefore, it is situated in the Applied Linguistics area, encompassing interdisciplinary fields, such as language teaching and learning, teacher education, language policies and internationalization of higher education.

The relevance of this study lies in some factors, namely: it is an investigation about an extremely recent institutional Program (as a language policy), therefore, with still very incipient literature, as evidenced in the literature review. Moreover, the research is conducted in an unprecedented context (UENP) and finally, and most importantly, it is worth noting that the studies on the subject have focused either on the linguistic contributions of the Program or on discourses/ideologies that underlie such language policy, thus neglecting issues related to teacher education. In this respect, this research study is the first one to address the relationship between the Program and the teacher education realm.

With the research design outlined, this study endeavors to describe and explain the extent to which the Paraná Speaks English Program can 
contribute to continuing teacher education. Furthermore, it aims to discuss future actions regarding teacher education through the institutional Program.

Aligned with the aims, the investigation is driven by the following questions: A) What contributions, if any, can the Paraná Speaks English Program bring to (continuing) teacher education? B) What future actions can be incorporated into the Program so as to boost the teacher education process?

In addition to this introduction, this paper is comprised of a review literature section, which covers a discussion on language policies and provides a systematized review of empirical research on the Paraná Speaks English Program. Moreover, there are a methodological and an analytical section, which summarizes the results found. Finally, some final considerations are proposed.

\section{The Paraná Speaks English Program at the Interface of Internationalization and Language Policies}

The Paraná Speaks Languages Program, as a language policy, emerges in an intense scenario of internationalization of higher education, which in turn shapes and is shaped by the so-called globalization, experienced by contemporary societies (ALTBACH; KNIGHT, 2007; DELGADO-MÁRQUEZ; HURTADO-TORRES; BONDAR, 2011). Internationalization is construed as a multifaceted phenomenon, for it is associated with numerous actions such as mobility, joint partnerships (e.g., research, teaching, curriculum) and many others.

Moreover, Altbach and Knight (2007) aver that the internationalization of higher education also entails language policies. As a matter of fact, such policies, which can be academic and/or governmental, are a strategy that institutions use to cope with the globalized world (ALTBACH; REISBERG; RUMBLEY, 2009). In this respect, internationalizing a certain institution proves necessary, as the exchange of knowledge/information triggers the progress of such institutions (MENDES, 2012).

Hornberger (2006) argues that language policies endeavor to transform a certain linguistic reality. In this context, the institutional Program is implemented by the Paraná state government (PARANÁ, 2014), so that state universities can tackle the rapid internationalization of higher education, as well as the transformation of societies on account of globalization.

Officially created in 2013, the first edition of the Program occurred from 2014 to 2017, its second edition between 2017-2019 and currently 
the third edition of the Paraná Speaks English Program is expected to be completed by 2021. The aims of the Program seem to have changed over time, for instance, in its first edition, the objectives of the Program were mainly mobility-based and therefore limited to international proficiency tests (aiming at academic mobility). Hence, the concept of internationalization, fostered by the Program, was centered on mobility. Conversely, however, such aims have been updated and currently the Program has a wide range of goals, as avowed on its official webpage (SETI, 2020, p. 1). Therefore, in addition to boosting the internationalization of higher education and providing linguistic training for students, faculty and staff, the Program seeks to:

a) Train coordinators to manage the courses in their higher education institutions;

b) Train language instructors to teach specific courses;

c) Offer preparatory courses for international English proficiency exams;

d) Offer general English, academic English, English for specific purposes and other courses, enhancing publications in high-impact international journals;

e) Offer courses to intensify the participation of the academic community in international events and prepare the academic community for the international research scenario, considering linguistic and cultural diversity;

f) Offer courses in strategic areas for international development of the university;

g) Foster partnership with English-speaking countries in order to promote joint actions for the qualification, strengthening and expansion of the Program.

It is relevant to stress that although the Program refers to languages in a broad sense, some aims clearly bespeak a monolingual perspective; in this case, English occupies a prestigious and hegemonic position (EL KADRI; DI RAIMO, 2017; MARSON, 2017). In this regard, English proves to be the major language in the internationalization process and such scenario corroborates the premise that internationalization is also a process propelled by political and economical variables (ALTBACH; KNIGHT, 2007).

\subsection{Research on the Program}

Inasmuch as the Program is still recent, currently in its third edition, the literature on the topic is expressively scarce. Through a search and 
literature review by means of the main national and international databases ${ }^{1}$ (ERIC, CAPES, SciELO and Google Scholar in English and Portuguese), using the search terms "Paraná Speaks Languages" and "Paraná Speaks English" (both in Portuguese and English), only six investigations were found: Marson and Borges (2015), El Kadri and Di Raimo (2017), Marson (2017), El Kadri, Gimenez and El Kadri (2019), Sanches (2019) and Senefonte (2019). Therefore, such research studies make up the literature review of the topic, as illustrated in Table 1 :

Table 1 - Research on the Paraná Speaks Languages Program

\begin{tabular}{c|c|c|c|c}
\hline Study & Type & Focus & Methodology & Context \\
\hline Di Raimo (2017) & Book Chapter & $\begin{array}{c}\text { Assumptions } \\
\text { /Ideologies } \\
\text { Related to the } \\
\text { Program }\end{array}$ & $\begin{array}{c}\text { Documentary } \\
\text { Data: news from } \\
\text { the government's } \\
\text { website }\end{array}$ & $\begin{array}{c}\text { The Program in } \\
\text { General }\end{array}$ \\
$\begin{array}{c}\text { Gimenez and } \\
\text { El Kadri (2019) }\end{array}$ & Journal Article & $\begin{array}{c}\text { Representations } \\
\text { and Perceptions } \\
\text { about the } \\
\text { Program }\end{array}$ & $\begin{array}{c}\text { Data: documentary } \\
\text { (news from the } \\
\text { government's } \\
\text { website) and } \\
\text { questionnaires }\end{array}$ & $\begin{array}{c}\text { The seven State } \\
\text { Universities }\end{array}$ \\
\hline Marson (2017) & $\begin{array}{c}\text { Master's } \\
\text { Dissertation }\end{array}$ & $\begin{array}{c}\text { Perceptions } \\
\text { about the } \\
\text { Program }\end{array}$ & $\begin{array}{c}\text { Data: documentary } \\
\text { (official regulatory } \\
\text { documents) and } \\
\text { questionnaires }\end{array}$ & $\begin{array}{c}\text { State University } \\
\text { of Londrina }\end{array}$ \\
\hline Borges (2015) & Journal Article & $\begin{array}{c}\text { Impacts of the } \\
\text { Program }\end{array}$ & $\begin{array}{c}\text { Data: documentary } \\
\text { (application forms) } \\
\text { and questionnaires }\end{array}$ & $\begin{array}{c}\text { State University } \\
\text { of Ponta Grossa }\end{array}$ \\
\hline Sanches (2019) & $\begin{array}{c}\text { Master's } \\
\text { Dissertation }\end{array}$ & $\begin{array}{c}\text { Conceptions of } \\
\text { Language }\end{array}$ & $\begin{array}{c}\text { Documentary Data } \\
\text { (textbook, reflexive } \\
\text { diaries, activities } \\
\text { and lesson plans) }\end{array}$ & $\begin{array}{c}\text { State University } \\
\text { of Paraná }\end{array}$ \\
\hline Senefonte (2019) & Journal Article & $\begin{array}{c}\text { Literature on the } \\
\text { Program }\end{array}$ & $\begin{array}{c}\text { Bibliographic } \\
\text { Method }\end{array}$ & $\begin{array}{c}\text { The Program in } \\
\text { General }\end{array}$ \\
\hline
\end{tabular}

Source: The author (based on SENEFONTE, 2019).

In order to investigate the assumptions that underlie the Paraná Speaks English Program (as a language policy), El Kadri and Di Raimo (2017) undertook a documentary study, whose data were comprised of news

\footnotetext{
${ }^{1}$ Education Resources Information Center (ERIC), Coordination for the Improvement of Higher Education in Brazil (CAPES) and Scientific Electronic Library Online (ScieELO).
} 
published on the government's official website. Their analysis suggests that the policy is ingrained with ideologies concerning monolingualism (of the English language), the commodification of English and native speakership. To conclude, the authors argue that the Program is fraught with hegemonic ideologies and such status quo necessitates being questioned.

Focusing on representations and perceptions, El Kadri, Gimenez and El Kadri (2019) conducted a qualitative research study, whose aim was to analyze official texts related to the Paraná Speaks English Program. Additionally, a questionnaire was administered to students and instructors (103 participants in toto). The authors conclude that there seems to be a divergence between the representations found in the official texts and those from the participants. Generally speaking, PSE is seen as an agent which is in charge of training people, promoting actions etc., whilst the Program personnel play the passive role. Furthermore, findings reveal a hegemonic discourse, in which English is construed as a commodity.

Marson (2017) investigated the first edition of the Program (20142016) seeking to understand the extent to which PSE could boost the internationalization of higher education. For such aim, the author examined official documents that regulate the Paraná Speaks English Program and deployed a questionnaire with PSE coordinators, instructors and students (77 participants). Results bespeak a positive linguistic contribution from the Program and consequently a boost to the internationalization of the university where the study was carried out. Nonetheless, the author defends that the Program still needs better planning and (re) arrangements and advocates for more debate on language policies.

Marson and Borges' (2015) research endeavored to present major results from the implementation of the first edition of the Paraná Speaks English Program at the State University of Ponta Grossa. By scrutinizing application forms and administering a questionnaire to 49 participants, the authors concluded that the Program brought positive contributions, especially in terms of language proficiency and professional/personal development.

In order to investigate conceptions of language in the textbook used by the Program at UNESPAR, Sanches (2019) conducted a qualitative, interpretive and autoethnographic study, involving a pre-intermediate class. The author avers that the Program is permeated with multiple conceptions of language, even though the textbook seems to prioritize language as 
code. Furthermore, the author reports on professional development as a contribution from the Program (although this was not the focus of the study).

Senefonte (2019) reviewed all the literature on the Paraná Speaks English Program (up to March of 2019). The bibliographic analysis reveals that the literature on PSE was centered on both virtual and real gains, the former involves expectations found in official documents and the latter represents concrete benefits experienced by research participants, especially with respect to academic mobility, as an outcome of the improvement in language proficiency. The author postulates that the body of literature on the Program is conspicuously scarce, nevertheless, the Program has proven to be a fruitful context for (future) research.

By delving into the literature on PSE, one can notice that the attention has substantially been placed on the impacts (benefits) of the Program on the higher education institutions where it has been deployed. Secondarily, there is an interest in the theoretical foundation that undergirds such language policy, especially with regard to conceptions of language (EL KADRI; DI RAIMO, 2017; EL KADRI; GIMENEZ; EL KADRI, 2019; SANCHES, 2019).

Notwithstanding the fact that one of the specific aims of the Program revolves around training language instructors (which is somewhat related to teacher education), there is no empirical research that specifically addresses the teacher education domain. In this regard, such absence strengthens the rationale of this study.

\section{Methodology}

As this research involves individuals in a particular social context, it is essentially qualitative (STRAUSS; CORBIN, 1998; VIDICH; LYMAN, 2006). Aligned with this nature, it incorporates a relativist ontological stance as well as a subjectivist epistemology (GUBA, 1990). Lastly, this is a case study, since it places emphasis on a certain real instance as a whole, that is, the process of teacher education in the Paraná Speaks English Program (COHEN; MANION; MORRISON, 2000).

As of the unit of analysis, this study focuses on teacher cognition, which is construed as a socially-constructed domain (BROWN; COLLINS; DUGUID, 1989; BIRELLO, 2012) and includes basically what people (teachers) think, know, believe and do (BORG, 2003). Hence, this research delves into teachers' thoughts, beliefs, knowledge, perceptions and their teaching practices. 


\subsection{Context and Participants}

As stated earlier the Paraná Speaks English Program serves the seven state universities in Paraná, and each has a team made up of 6 people: 1 institutional coordinator, 1 pedagogical coordinator, 3 language instructors and 1 administrative assistant. The participants of this investigation include only the instructors and the pedagogical coordinator.

This research mainly encompasses three English instructors, who have taught in the Program at the State University of Northern Paraná (UENP): Amanda, Irabelle and Renan. ${ }^{2}$ They all graduated from UENP and hold an undergraduate degree in Portuguese and English and a graduate certificate in English Teaching. Amanda and Izabelle have been in the Program since its first edition (in 2014), while Renan started in 2017 (in the second edition). Each instructor has three classes per semester and teaches pre-intermediate, intermediate and post-intermediate students.

The pedagogical coordinator is the researcher of this investigation. In this regard, as the pedagogical coordinator, I have been part of the PSE team since its second edition and I am in charge of providing pedagogical (group and individual) counselling. As the researcher, I mediated theoretical sessions (from which the data were generated), took notes and interviewed the instructors.

As part of the pedagogical counselling, the coordinator held meetings with the instructors in which they could report on their teaching experiences in the classroom. As a matter of fact, the meetings concerned a problemsolving nature, the instructors' major concerns involved technology, grammar instruction and language variation. With this in mind, the instructor decided to hold theoretical-methodological meetings in order to discuss texts that address some issues experienced by the instructors in the classroom. In this regard, the coordinator (researcher) expected to both enable space for the instructors to share their experiences and provide them with some theoretical knowledge, so that they could be better prepared to tackle some pedagogical-didactical issues that arose in class.

\footnotetext{
${ }^{2}$ As indicated in the informed consent, the participants opted to be referred to by their real names.
} 


\subsection{Data Generation and Analysis}

The data derive from: a) three theoretical sessions with the participants, which totals six hours in all and b) a semi-structured, audio-recorded interview. ${ }^{3}$ The researcher took notes of each session and transcribed the interviews and after that, both datasets were combined into one single file (7 pages long) and the pages numbered (from 1-292). It is important to mention that the transcription was submitted to the participants so they could validate its content. Table 1 illustrates the data generation procedures:

TABLE 2 - Data Generation Procedures

\begin{tabular}{c|c|l}
\hline Date & Procedure & \multicolumn{1}{c}{ Content } \\
\hline March 08, 2019 & Session 1 & $\begin{array}{l}\text { WhatsApp as a Tool for English Teaching and } \\
\text { Learning (SENEFONTE; TALAVERA, 2018) }\end{array}$ \\
\hline March 22, 2019 & Session 2 & $\begin{array}{l}\text { Sociolinguistics \& English language studies } \\
\text { (BLOMMAERT, 2012) }\end{array}$ \\
\hline April 05, 2019 & Session 3 & $\begin{array}{l}\text { Towards a Pedagogy of Grammar Instruction } \\
\text { (RICHARDS; REPPEN, 2014) }\end{array}$ \\
\hline April 12, 2019 & $\begin{array}{c}\text { Interview with } \\
\text { Amanda }\end{array}$ & --- \\
\hline April 19, 2019 & Interview with Izabelle & --- \\
\hline April 26, 2019 & Interview with Renan & --- \\
\hline
\end{tabular}

Source: The author.

As expounded earlier, the texts were selected ${ }^{4}$ so as to meet the instructors' didactic-pedagogical needs. Hence, the topics are centered on

\footnotetext{
${ }^{3}$ The interview was made up of the following questions: 1 . What importance, if any, were the theoretical discussions to your education as a teacher? Explain; 2. What importance, if any, is the Paraná Speaks English Program (as a whole) to your education as a teacher? Explain; 3. Which aspects of the Program are directly associated with teacher education? Explain; 4. Which actions could be implemented (by the Program) in order to improve (continuing) teacher education? Explain; 5. Would you like to add anything? (comments, suggestions, questions etc.)?

${ }^{4}$ Following similar procedures for the literature review, the selection of the texts included national and international databases, peer-reviewed papers which were published less than 10 years ago. Initially, the coordinator (researcher) chose some texts for each topic (technology, grammar and sociolinguistics), and then the instructors jointly chose one text for each theme.
} 
grammar instruction, technology in the classroom and language variation (sociolinguistics). For each meeting, all the instructors and the coordinator were required to read the texts so that the discussions could be more fruitful.

Session 1 covered Senefonte and Talavera (2018), whose text is a didactic proposal for English teaching-learning (both oral and written skills) through WhatsApp. The instructors highlighted the relevance of the proposal, as the app is part of teachers' and students' lives and such application serves as a tool for numerous instances of language practices.

In session 2, Blommaert's (2012) insightful paper delves into the implications of the pervasiveness of English all over the globe. By and large, the instructors voiced their concern about the challenges of teaching a deterritorialized language that is in constant transformation, as it encounters disparate people, cultures and other languages.

Session 3 addressed Richards and Reppen (2014) who provide some guidelines for grammar instruction. The instructors acknowledged the relevance of the text, since it has a practical nature and the ideas presented can be immediately implemented in class. Moreover, the participants argue that grammar instruction is a topic that still raises many questions and teachers should be prepared to approach it in a purposeful way.

Once the meetings were held, each instructor was interviewed. As signaled earlier, the focus of the interview was on the entire process of the theoretical discussions and not on the content of a specific text.

After all the data were generated and prepared for analysis, the analytical process began. In this regard, I corroborate that such process is highly abstract and requires a dense cognitive ability from the researcher (STRAUSS; CORBIN, 1998). In addition, the qualitative analysis focused on the content of the data-content Analysis/CA-(BARDIN, 1977), which encompasses reduction, categorization and classification of the data.

In line with such premises, I also adopt the Paradigmatic and Syntagmatic Analysis -PSA - (REIS, 2018), a method and methodology that fosters some principles such as: avoidance of paraphrases in data classification, implications of language use (the relationship between language and power), coherence in data categorization, especially regarding coordination and subordination. In this sense, the Paradigmatic and Syntagmatic Analysis is concerned about the appropriate hypernymic/ hyponymic interconnectedness that emerges in the analytical process. 


\subsection{Ethical Considerations}

The research (project) was submitted to the Ethics Committee of the State University of Northern Paraná and approved accordingly, ${ }^{5}$ as a way to ensure the rights of research participants and ensure ethical conduct throughout all the stages of the study. The research participants signed a free and informed consent form (ICF) attesting that they were aware of (and agreed with) the processes/ procedures involved in the research. Besides, the coordinator in charge of the research context (PSE's office at UENP) signed a statement validating authorization for conducting the research.

With this in mind, the informed consent form is supported by Resolution no. 466, December 12, 2012 (NATIONAL HEALTH COUNCIL, 2012), the (UK) Ethical Guidelines for Educational Research (BERA, 2018), and the American Educational Research Association -Code of Ethics- (AERA, 2011).

\section{The Paraná Speaks English Program and Teacher Education: A Qualitative Analysis}

Once the data were scrutinized, reduced and categorized, drawing upon qualitative data analysis principles, the final classification (from the researcher's inductive-deductive analytical action) is centered on challenges and benefits, as detailed in the following subsections:

\subsection{Challenges}

Teacher education in the Paraná Speaks English Program is marked by challenges, which include didactic-pedagogical, administrative and education domains:

${ }^{5}$ Certificate of Ethical Approval (CAAE, acronym in Portuguese), number: 13002719.0.0000.8123. 
Table 3 - Data Classification: Challenges

\begin{tabular}{c|l|l}
\hline \multicolumn{1}{c|}{ Hypernym } & \multicolumn{1}{|c|}{ Hyponyms } & \multicolumn{1}{c}{ Subhyponyms } \\
\hline \multirow{4}{*}{ Challenges } & Didactic-Pedagogical Resources & $\begin{array}{l}\text { Material Issues } \\
\text { Human Issues }\end{array}$ \\
\cline { 2 - 3 } & Administrative & -- \\
\cline { 2 - 3 } & Education & -- \\
\hline
\end{tabular}

Source: The author.

Concerning didactic-pedagogical challenges, they can be related to material and human issues. The following excerpts illustrate the former:

Renan voices his concern about the complexities of our work tool (English). The instructor explicates that this 'status' of English demands a lot of knowledge and abilities, because the language has incorporated numerous features according to a certain region and culture. (Researcher, L. 101-103).

Amanda mentions that grammar is more complex than it seems to be, as it is not only a set of rules to be followed, but it is a resource on which a certain language is structured, so it is necessary for any communicative event. (Researcher, L. 118-120).

In this respect, Izabelle comments on some textbooks employed in their teaching context; she mentions that the majority of such material focuses only on standard language, therefore, they focus on one piece the language. She complements that some materials have lessons with excessive amount of grammar points, which tend to make the lesson boring. (Researcher, L. 127-130).

The first two examples illustrate challenges regarding the English language itself. The fact that the language has moved towards paramountcy in a globalized world poses some challenges in regard to its teaching and learning (GIMENEZ; CALVO; EL KADRI, 2011; JENKINS, 2015). In this sense, teaching a deterritorialized language implies a paradigmatic change, which in turn involves questioning native speakership, language varieties, discourse issues (hegemonic ideologies) and so forth. Needless to say, such change brings forth pedagogical implications, such as the choice of a 
certain variety to cover in the classroom, for instance. As evidenced in the literature review section, the Paraná Speaks English Program still seems to uphold a more 'monolingual' and 'homogenous' perspective with respect to English (EL KADRI, DI RAIMO, 2017; MARSON, 2017). In this regard, there seems to be a conflict between the philosophies to which the Program subscribes and the demands of a globalized world, which brings impacts on the English language and such impacts are experienced by individuals in the language teaching-learning context (viz.: PSE).

The third excerpt is associated with a didactical-pedagogical hindrance on account of didactic materials. In other words, the teaching material seems to have some gaps, since it has trouble coping with current trends in language teaching/learning, such as: the status of English in the globalized world (MIRANDA, 2015) and grammar instruction (RODRIGUES, 2005), as illustrated in the excerpts. Nonetheless, this discussion could also encompass text/discursive genres (CRISTÓVÃO, 2018), critical and digital literacy (GIRÓN-GARCÍA, 2015, ZHANG, 2015) and language variation (RODRIGUES, 2005; FRANCESCON; SENEFONTE; BARONAS, 2013), to name a few.

In addition to material challenges, the data bespeak some difficulties with regard to human issues:

She complements that some materials have lessons with excessive amount of grammar points, which tend to make the lesson boring.

The researcher then questions the relationship between grammar instruction and students' lack of interest.

Izabelle ventures the opinion that grammar is associated with rules, memorization and fixed structures, which in turn may cause students' demotivation. (Researcher, L. 129-134).

It is worth stating that such problem can be associated with student dropouts (MARSON, 2017; RIOS; SENEFONTE, 2021), even though such premise is not explicitly voiced by the participants. Certainly, these dropouts not only result from didactic-pedagogical factors, but also from social and

\footnotetext{
${ }^{6}$ Although the latest editions have occasionally included languages other than English (viz., Spanish and French) at some universities served by the Program, the focus of PSE (as a whole) is still on English.
} 
affective variables. Hence, the instructors in the program also experience challenges regarding student dropouts, as the rates are considerably high (RIOS; SENEFONTE, 2021).

Besides didactic-pedagogical hindrance, administrative challenges are also faced by the participants, as follows:

(...) calls attention to the privacy issue, since students will have teachers' phone numbers and this can cause an invasion of privacy. The instructor illustrates his ideas providing a personal example: his students sometimes send him messages at inappropriate times and about contents that are not necessarily related to the classes or the language.

Amanda reports some personal experiences in this respect and reiterates the invasion of privacy caused by the application. (Researcher, L. 25-31).

As the instructors and the administrative assistant constantly contact the students via WhatsApp for different purposes (e.g. announcements), they occasionally face this administrative challenge. As argued by Senefonte and Talavera (2018), the application has its positive and negative sides and the teacher should establish the rules about its use. As PSE instructors are also in charge of some administrative issues, ${ }^{7}$ administrative challenges are part of their continuing teacher education in the Program.

The participants also have challenges as of their education in the Program, as illustrated by the data:

Izabelle contends that although such topic is part of students' everyday routine, there is a considerable paucity of research on the relationship between the application and English teaching and learning. (Researcher, L. 15-17).

I think the program could contribute to our teacher education, so sometimes we have to be prepared to enter the classroom and some courses are very specific, so I think the program

\footnotetext{
${ }^{7}$ The instructors generally contact the students throughout the semester, mediate the purchase of the textbook, contact technical assistance, publicize the courses offered per semester and others.
} 
could offer more training courses, so that I could be more prepared for these situations. (Amanda, L. 196-199).

I believe if we had more training, so training from Smrt English, ${ }^{8}$ training from other universities, this could be really helpful for us, so if we had more contact with other English teachers from other universities, I don't know how this could be done, but it could also be helpful, because we could compare what we are doing and try to actually learn with other universities as well and this could be something to improve our program here and help other teachers from other universities to improve their programs as well. (Renan, L. 282-287).

I think that the discussions on theoretical research studies and the sharing of experiences are the most enriching actions that could be done. In addition, teachers and coordinators could watch each other's classes and try to improve the teaching skills, allying the theoretical discussions with the practices in the classroom. (Izabelle, L. 229-232).

As evidenced in the excerpts, the challenges as of teacher education in the Program concern research and practice. In other words, the participants express a need for theoretical and practical knowledge. The first excerpt indicates that the theoretical knowledge is hindered by a dearth of empirical research on some current topics: in the case above, a technological application for English teaching and learning (WhatsApp) (SENEFONTE; TALAVERA, 2018). It is worth mentioning that such scarcity of literature is related to the gaps in didactic material, as shown earlier in the section.

The excerpts also signal that the theoretical hindrance is potentially minimized by means of theoretical discussions, as the case of the university in which this research was carried out. Nonetheless, it is uncertain whether such actions hold true at the other universities served by the Program. In this respect, the data also bespeak a need for more integration among the institutions involved, which seem to operate individually in the Program. In addition to the theoretical knowledge, the instructors' answers imply a need for more actions/initiatives in terms of (teaching) practices. In a nutshell, the participants seem to claim a professional socialization (LORTIE, 1975).

\footnotetext{
${ }^{8}$ It is a digital platform for language teaching-learning that offers the Paraná Speaks English Program both the didactic material to be employed and the placement tests administered.
} 


\subsection{Benefits}

In addition to challenges, the teacher education process in the Program is characterized by benefits, which encompass pragmatic, cognitive and empowerment gains:

TABLE 4 - Data Classification: Benefits

\begin{tabular}{l|l|l}
\hline Hypernym & \multicolumn{1}{|c|}{ Hyponyms } & \multicolumn{1}{c}{ Subhyponyms } \\
\hline \multirow{4}{*}{ Benefits } & Pragmatic & $\begin{array}{l}\text { Didactic-Pedagogical Resources } \\
\text { Interpersonal Relationship }\end{array}$ \\
\cline { 2 - 3 } & Cognitive & $\begin{array}{l}\text { Theoretical-Methodological Knowledge } \\
\text { Linguistic Knowledge }\end{array}$ \\
\cline { 2 - 3 } & Empowerment & -- \\
\hline
\end{tabular}

Source: The author.

The pragmatic benefits can be classified as didactic-pedagogical, resources and interpersonal relationship. The following data illustrate the first type:

Amanda reinforces the relevance of the application, for the famous four language skills (listening, speaking, reading and writing) can be developed. She mentions the teaching proposals of the paper to illustrate that: when students send audio messages, which is a way to develop speaking, and the others in the group listen and reply to such messages, which is a way to concomitantly develop listening and speaking skills. Additionally, she mentions that fact the links and texts can be used via WhatsApp which is a way to explore reading and, finally, typing messages as a way to increase writing skills. (Researcher, L. 46-53).

So I think that by studying something that is theoretical, something like this can help me a lot inside the classroom. (Amanda, L. 177-178).

Some discussions were very interesting because they brought issues that we have not yet discussed before, such as how to use WhatsApp with the students, or how to deal with the grammar contents. (Izabelle, L. 210-212).

We could understand better the issues we were facing, the problems we were going to face in the future and try to predict 
some of them, so we can have something to go for when thinking about problems in the classroom and new strategies for English teaching, since we had the theory covered to draw on and this is really helpful, because we not only discuss things according to the practice, you know? (...) We are actually comparing things, we are actually joining practices and theory and this would be the ideal. (Renan, L. 251-257).

The excerpts signalize a didactic-pedagogical benefit that results from both the technological resources available (in the Program) and the theoretical discussions provided. From both situations, the participants have some gains in terms of (practical) methods to be implemented in the classroom.

Aside from the didactic-pedagogical domain, the data reveal a benefit related to resources:

The instructor contends that application serves heterogeneous purposes, since it enables prompt communication with the students and also it is a space for learning, as the communication is in English, the teacher makes interventions when necessary, so that students can learn from their mistakes (Researcher, L. 5-9).

Amanda then argues that technology plays a significant role in this discussion, as it is a substantial vehicle for language practices, which involve not only communicative, but also teaching-learning events. (Researcher, L. 108-110).

In the excerpts, a benefit from technological resources can be evidenced. In this case, such benefit enables administrative actions (announcements, for instance). Despite the fact that the two excerpts also cover a didactical-pedagogical nature, the focus of this part of the analysis (this data classification) is only on the benefits in terms of material resources and not on didactic-pedagogical issues, as these were already illustrated earlier in this section.

The last pragmatic gain concerns interpersonal relationship, which was verbalized by two participants:

(...) and put me out of my comfort zone, dealing with students from different realities. I learned how to be more humane, how to understand the other's difficulties and the experience we had with the Fulbright English Teacher Assistants, getting in touch 
with native teachers was the best part! I just have to thank all the coordinators and professionals from the program for letting me have this great opportunity! (Izabelle, L. 236-241).

Since I could be in contact with a different audience (...) if I compare with the audience from the other programs I have worked in (...) Since, I'm inside the university, I'm dealing with more academic English, dealing with professors, with people from different areas and I need to think about different strategies to teach English and different strategies to use technology and other tools in the classroom. The Paraná Speaks English Program was indeed of great help for my education as a teacher, especially because we Could, (...) because I could talk to other professors, professors from different areas and understand better the issues they face (...) professors that needed to learn English, university students that needed to learn English as well and also other English teachers and we could discuss problems were facing in the classroom together, since we are doing kind of the same thing (...) So this was really helpful for my education as a teacher. (Renan, L. 260-271).

The data seem to be aligned with the literature in teacher education, as such professional socialization is part of (continuing) teacher education (LORTIE, 1975). Moreover, it is part of one's identity; in this case, this professional socialization is ingrained in teacher identity (REIS; VAN VEEN; GIMINEZ, 2011).

Besides pragmatic benefits, the Program brings some cognitive gains, in terms of theoretical-methodological and linguistic knowledge:

Izabelle stresses that such fact promotes a resignification of the concept of language, as language goes beyond a fixed system of morphological, syntactical, phonological structures. Language can be 'constructed' in a certain communicative event for meaning-making purposes. Thus, language is multifaceted and unstable. (Researcher, L. 73-76).

I realized that I have improved a lot (...) my skills, my teaching skills. So, I have learned a lot, so I think that now I'm a better teacher than before, so I've learned lots of things that I didn't know before and that's really good for my career. (Amanda, L. 185-187). 
I suppose that the theoretical discussions increased my knowledge as a teacher in general; not only as a researcher, but also related to my teaching skills and my practice inside the classroom. (Izabelle, L. 208-210).

I believe the theoretical discussions (...) they were of great help for my education as a teacher in the program, since we could really compare things between practice and theory and could discuss how to balance that. (Renan, L. 248-250).

In my opinion, being a teacher of the Paraná Speaks English Program gave me more than teaching skills. It made me improve my English in general. (Izabelle, L. 235-236).

The first four excerpts indicate a theoretical-methodological knowledge gained from the Program, whilst the last concerns linguistic knowledge. Once again, it is imperative to point that such benefits are the corollary of actions taken at UENP (context of this research), as the pedagogical coordinator holds theoretical sessions and other (counselling) meetings in English; this way, such actions can benefit the instructors both in terms of theoretical-methodological and linguistic knowledge. Nevertheless, one cannot assume that such benefit is a characteristic of the Program as a whole, as this is a reality of only one university where the Program operates and it is rather uncertain whether the other institutions take similar actions, therefore more research proves to be necessary to tackle this question.

The last class of benefits is attached to empowerment as a gain obtained from the Program (and from this research):

Renan states the group sessions were extremely helpful, because they promoted reflective activities, gave voice to the instructors to express their thoughts, feelings, impression and so on. (Researcher, L. 164-166).

(...) I can share it with the other professors, I can share my concerns, I can share my observations, I can share maybe some suggestions. (Amanda, L. 175-177).

As of the Program, again, it is worth mentioning that such empowerment comes from actions taken only by one specific institution. In the excerpts, the space given to the participants to engage in the research is an indication of empowerment (SENEFONTE, 2018). Moreover, the cognitive gains expounded earlier can also be seen as an empowerment tool, as endorsed by D'Almas (2016). 


\subsection{Return of Data Analysis}

Once the data were analyzed and reported, the analytical report was sent to the participants. As pointed out by Senefonte (2018), such procedure serves both validation of the analysis (as it is a way of triangulation) and also empowerment purposes, since it gives voice to research participants; most importantly, it allows the participant to edit the analysis and to feel they are really participating in the knowledge construction process mediated by the study. In this regard, the research endeavored to be an empowering study as well (CAMERON, 1992).

Bearing this in mind, between August and October of 2019, a questionnaire9 (with open and closed-ended questions) was sent to the participants so that they could agree/disagree with the analysis or make comments or suggest changes, which would be incorporated to the final version of the paper.

Only two participants returned the questionnaire and their answers indicate that they fully agree with the analysis and with the way they are reported in this study. Additionally, none of them expressed wish to change the analysis. This way, the final analytical report of this research was validated by the participants.

\section{Final Considerations}

Seeking to describe and explain the extent to which the Paraná Speaks English Program can contribute to continuing teacher education and to discuss future actions regarding teacher education through the institutional Program, this study was undertaken at the State University of Northern Paraná (UENP), which is one higher education institution served by the Program. By means of theoretical sessions, interviews and questionnaires,

\footnotetext{
${ }^{9} 1$. Do you agree with the analysis in general? ( ) yes ( ) no ( ) partially; 2. Is there any part of the analysis you disagree with? ( ) yes ( ) no; 3. In case of affirmative answer to the previous question, indicate the part you disagree with and explain why; 4 . Is there any part of the analysis you would change? () yes () no; 5 . In case of affirmative answer to the previous question, indicate what and how you would change the analysis; 6 . Are you comfortable with they way you and your data are reported in the research? ( ) yes ( ) no () partially; 7. In case your answer was negative or partially to the previous question, explain; 8. Do you have any comments, suggestions?
} 
the research involved three English instructors and one pedagogical coordinator and the results are expressed as answers to the research inquiries:

A) What contributions, if any, can the Paraná Speaks English Program bring to (continuing) teacher education? Grounded in the data, it is possible to postulate that the Paraná Speaks English Program at UENP can contribute significantly to continuing teacher education, as it brings benefits in terms of pragmatic gains, which include didactic-pedagogical, resources and interpersonal (socialization) issues. Furthermore, the benefits include a cognitive domain, as teachers' theoretical-methodological and linguistic knowledge are enhanced by actions taken in the Program. Finally, such actions can also promote, to some extent, empowerment.

B) What future actions can be incorporated into the Program so as to boost the teacher education process? The data reveal some challenges experienced by the teachers in the Program, and such challenges suggest that some actions could be taken so as to minimize these drawbacks. First, the didactic material is fraught with substantial gaps in terms of currents trends in language teaching and learning. In other words, important issues such as, inter alia, the status of English, language variation and grammar instruction (based on contemporary perspectives) are not appropriately addressed. As a result, teachers face didactic-pedagogical challenges. Such questions raise a bigger discussion on the (ideological and theoretical) foundations that underlie the Program, as a language policy (MARSON, 2017; EL KADRI; GIMENEZ; EL KADRI, 2019). In this sense, as the Program is progressing (currently in its third edition) and has aspirations to consolidate as a permanent institutional program, it is imperative that this language policy address important discussions that revolve around the language teaching, learning and teacher education scenario.

Moreover, the data signal a need for more research that tackles questions related to language learning and teaching, didactic-material, language policies, language ideologies, student dropouts, to name a few. As of didactic material, for example, the data of this research reveal gaps, which are perceived only from the teachers' standpoint. Hence, this is a question that gives rise to more investigation, especially in terms of studies that focus on the material (analysis). 
Lastly, the data also indicate that the seven universities served by the Program work individually with regard to actions around teacher education and this in turn is seen by the teachers as something negative. In other words, the participants' cognition unveils a need for more integration among the institutions involved.

Such integration includes principally knowledge/experience sharing and training for the ordinary and new demands of the Program. In its third edition, for example, the Program began offering courses of a different nature, such as Academic English (focusing on international publications) and English as a Medium of Instruction. Needless to say, such courses go beyond a metalinguistic domain (the one the instructors are accustomed to) and require a theoretical, methodological and linguistic knowledge that they may not have and that is why their data suggest an indication for more training offered by the Program, Smrt English or by other institutions.

Inasmuch as the Program is considerably multiplex, it subsumes numerous fields of investigation, as avowed earlier and therefore, it has proved to be an authentic and promising context of prospective research (SENEFONTE, 2019). In this regard, this study is an invitation for future research, especially on teacher education mediated by the Program, as it has been scarcely addressed. As a matter of fact, the Program is still a recent policy and has a long way to go; in the meantime, this is an opportunity for numerous possibilities for research in the Applied Linguistics area and closely-related fields.

\section{References}

ALTBACH, P. G.; KNIGHT, J. The Internationalization of Higher Education: Motivations and Realities. Journal of Studies in International Education, [S.l.], v. 11, n. 3/4, p. 290-305, 2007. DOI: https://doi.org/10.1177/1028315307303542

ALTBACH, P.; REISBERG, L.; RUMBLEY, L. Trends in Global Higher Education, Tracking an Academic Revolution. Paris: UNESCO, 2009. DOI: https://doi. org/10.1163/9789004406155

AMERICAN EDUCATIONAL RESEARCH ASSOCIATION. Code of Ethics. 2011. Available at: http://c.ymcdn.com/sites/www.weraonline.org/resource/ resmgr/a_general/ aera.pdf. Accessed on: Feb. 2020.

BARDIN, L. Análise de conteúdo. Lisboa: Persona, 1977. 
BERA. Ethical Guidelines for Educational Research. 2018. Available at: http://www. bera.ac.uk/ Accessed on: Feb. 2020.

BIRELLO, M. Teacher Cognition and Language Teacher Education: beliefs and practice. A conversation with Simon Borg. Bellaterra Journal of Teaching \& Learning Language \& Literature, Barcelona, v. 5, n. 2, p. 88-94, 2012. DOI: https://doi. org $/ 10.5565 / \mathrm{rev} / \mathrm{jtl} 3.464$

BLOMMAERT, J. Sociolinguistics \& English Language Studies. Working Papers in Urban Language \& Literacies, London, paper 85, p. 2-17, 2012.

BORG, S. Teacher Cognition in Language Teaching: A Review of Research on What Language Teacher Think, Know, Believe and Do. Language Teaching. Cambridge, v. 36, p. 81-109, 2003. DOI: https://doi.org/10.1017/S0261444803001903

BROWN, J. S.; COLLINS, A.; DUGUID, P. Situated Cognition and the Culture of Learning. Educational Researcher, [S.l.], v. 18, n. 01, p. 32-42, 1989. DOI: https:// doi.org/10.3102/0013189X018001032

COHEN, L.; MANION, L.; MORRISON, K. Case studies. In: COHEN, L.; MANION, L.; MORRISON, K. (ed.). Research Methods in Education. London; New York: Routledge, 2000. p. 105-133.

CAMERON, D. et al. Researching Language: Issues of Power and Method. London; New York: Routledge, 1992.

CONSELHO NACIONAL DE SAÚDE (BRASIL). Resolução n. 466, de 12 de dezembro de 2012. Trata de pesquisas em seres humanos e atualiza a resolução 196. Brasília, 2012. Available at: http://www.conselho.saude.gov. br/web_comissoes/conep/index.html. Accessed on: Feb. 2020.

CRISTÓVÃO, V. L. L. (org.). Gêneros textuais/discursivos: ensino e educação (inicial e continuada) de professores de línguas. Campinas: Mercado de Letras, 2018.

D'ALMAS, J. Da passividade à agência: desenvolvimento de professoras como resultado de empoderamento. 2016. 307f. Tese (Doutorado em Estudos da Linguagem) - Universidade Estadual de Londrina, Londrina, 2016.

DELGADO-MÁRQUEZ, B. L.; HURTADO-TORRES, N. E.; BONDAR, Y. Internationalization of Higher Education: Theoretical and Empirical Investigation of Its Influence on University Institution Rankings. Revista de Universidady Sociedad del Conocimiento (RUSC), [S.l.], v. 8, n. 2, p. 265-284, 2011. DOI: https://doi. org/10.7238/rusc.v8i2.1069

EL KADRI, A.; DI RAIMO, V. Globalization and the Teaching of Foreign Languages: The Case of Paraná Speaks English Program. In: GIMENEZ, T. et al. 
(ed.). Language Issues in a Global World: Insights from Brazil. Londrina: Edição do Autor, 2017. p. 64-73.

EL KADRI, M. S; GIMENEZ, T; EL KADRI, A. Representações sobre o programa "Paraná Fala Idiomas - Inglês" sob as lentes do Ciclo de Política e da Análise do Discurso Crítica. Entrepalavras, Fortaleza, v. 9, n. 3, p. 421-441, set-dez. 2019. DOI: https://doi.org/10.22168/2237-6321-31449

FRANCESCON, P. K.; SENEFONTE, F. H. R.; BARONAS, J. E. A. Variação linguística no ensino de língua inglesa. Revista Entrelinhas, São Leopoldo, v. 7, n. 2, p. 209-221, 2013.

GIMENEZ, T.; CALVO, L. C. S.; EL KADRI, M. S. Inglês como Lingua Franca: ensinoaprendizagem e formação de professores. Campinas, SP: Pontes Editores, 2011.

GIRÓN-GARCÍA, C. Literacy and Technologies in EFL Settings: Fostering Reading Comprehension on the Internet. Bellaterra Journal of Teaching \& Learning Language \& Literature, Barcelona, v. 8, n. 2, p. 69-100, May-Jun. 2015. DOI: https:// doi.org/10.5565/rev/jt13.616

GUBA, E. C. The Paradigm Dialog. North Carolina: Appalachian State University, 1990.

HORNBERGER, N. Frameworks and Models in Language Policy and Planning. In: RICENTO, T. (ed.). An Introduction to Language Policy: Theory and Method. Oxford: Blackwell Publishing, 2006. p. 10-28.

JENKINS, J. Repositioning English and Multilingualism in ELF. Englishes in Practice, Southampton, v. 2, n. 3, p. 49-85, 2015. DOI: https:/ /doi.org/10.1515/eip-2015-0003 LORTIE, D. The Limits of Socialization. In: D. LORTIE. (ed). Schoolteacher: A Sociological Study. Chicago: The University of Chicago Press, 1975. p. 185-210.

MARSON, M. Z. Ensino de inglês e a internacionalização do ensino superior: percepções sobre o Programa "Paraná Fala Inglês" na UEL. 2017. 115f. Dissertação (Mestrado em Estudos da Linguagem) - Universidade Estadual de Londrina, Londrina, 2017. MARSON, I. C. V.; BORGES, E. F. V. "Paraná Fala Inglês" na UEPG: experiência extensionista com foco na mobilidade internacional. Extensio-UFSC-Revista Eletrônica de Extensão, Florianópolis, v. 12, n. 20, p. 73-89, 2015. DOI: https:/ /doi. org/10.5007/1807-0221.2015v12n20p73

MENDES, F. Z. A Internacionalização do Ensino Superior: uma análise da estrutura e processos organizacionais da Assessoria de Relações Internacionais em uma universidade. 2012. 80f. Monografia. (Especialização em Gestão Pública) Universidade Federal do Rio Grande do Sul, Quaraí, 2012. 
MIRANDA, F. C. Análise de colecõoes didáticas indicadas pelo Programa Nacional de Livros Didáticos para o Ensino Médio, sob a perspectiva do inglês como língua franca. 2015. $157 \mathrm{f}$. Dissertação (Mestrado em Estudos da Linguagem) - Universidade Estadual de Londrina, Londrina, 2015.

PARANÁ. Secretaria da Ciência, Tecnologia e Ensino Superior. Termo de Cooperação entre a SETI - Fundo Paraná / Unidade Gestora do Fundo Paraná - UGF e a UEL. TC N. 024/14. Curitiba: SETI/UGF, 2014.

REIS, S. Paradigmatic and Syntagmatic Analysis in Qualitative Research with Data of Human Language. Signum: Estudos da Linguagem, Londrina, v. 21, n. 2, p. 147-171, 2018. DOI: https://doi.org/10.5433/2237-4876.2018v21n2p147

REIS, S; VAN VEEN, K.; GIMENEZ, T. (org.). Identidades de professores de línguas. Londrina: Eduel, 2011.

RICHARDS, J. C.; REPPEN, R. Towards a Pedagogy of Grammar Instruction. RELC Journal, London, v. 45, n. 1, p. 5-25, 2014.

RIOS, E. S.; SENEFONTE, F. H. R. O Paraná Fala Inglês na Universidade Estadual do Norte do Paraná: um estudo documental. In: RIOS, E. S.; NOVELLI, J.; CALVO, L. C. S. (org.). Paraná Fala Idiomas-Inglês: pesquisas, práticas e desafios de uma política linguística de estado. São Paulo: Pontes, 2021. v. 1, p. 77-98.

RODRIGUES, D. S. O tratamento da variação linguística nos livros de didáticos de língua inglesa. 2005. 83f. Dissertação (Mestrado em Linguística Aplicada) - Universidade Estadual do Ceará, Fortaleza, 2005.

SANCHES, G. J. O programa Paraná Fala Inglês: uma autoetnografia sobre concepção de língua e uso de material didático em sala de aula. 2019. 162f. Dissertação (Mestrado em Letras) - Universidade Federal do Paraná, Curitiba, 2019.

SENEFONTE, F. H. R. Informal English: Learning, Teaching and Teacher Education. 2018. 601f. Thesis (Doctoral Degree in Language Studies) - State University of Londrina, Londrina, 2018.

SENEFONTE, F. H. R. Research on the Paraná Speaks English Program: a bibliographic analysis. Claraboia, Jacarezinho-PR, v. 12, p. 89-98, jul-dez, 2019.

SENEFONTE, F. H. R.; TALAVERA, M. N. G. O WhatsApp como ferramenta para o ensino-aprendizagem de língua inglesa. Entretextos, Londrina, v. 18, n.1, p. 241-264, 2018. DOI: https://doi.org/10.5433/1519-5392.2018v18n1Supl.p241

SETI. O Paraná Fala Inglês: site oficial. 2020. Availabe at: http:/ /www.seti.pr.gov.br/ ugf/programas/paranafalaidiomas/apresentacao. Accessed on Feb. 2020 
STRAUSS, A.; CORBIN, J. Basics of Qualitative Research: Techniques and Procedures for Developing Grounded Theory. 2. ed. Thousands Oaks: Sage Publications, 1998. VIDICH, A. J.; LYMAN, S. M. Métodos qualitativos: sua história na sociologia e na antropologia. In: DENZIN, N. K.; LINCOLN, Y. S. (ed.). Planejamento da Pesquisa Qualitativa. Tradução de Sandra Regina Netz. Porto Alegre: Artmed, 2006. p. 49-90. ZHANG, G. Learning Critical Literacy in ESL Classrooms. Creative Education, Spain, v. 6, p. 1316-1321, 2015. DOI: https://doi.org/10.4236/ce.2015.612131

Data de submissão: 30/03/2020. Data de aprovação: 22/01/2021. 